\title{
An Introduction to U.S. Collective Bargaining and Labor Relations
}





\section{Harry C. Katz,}

Thomas A. Kochan, and

Alexander J. S. Colvin

\section{An Introduction to U.S. Collective Bargaining and Labor Relations}

\section{FIFTH EDITION}

ILR Press

an imprint of

Cornell University Press

Ithaca and London 


\section{Copyright (C) 2017 by Cornell University}

All rights reserved. Except for brief quotations in a review, this book, or parts thereof, must not be reproduced in any form without permission in writing from the publisher. For information, address Cornell University Press, Sage House, 512 East State Street, Ithaca, New York 14850.

First published 2017 by Cornell University Press

Printed in the United States of America

Library of Congress Cataloging-in-Publication Data

Names: Katz, Harry C. (Harry Charles), 1951- author. | Kochan, Thomas A., author. | Colvin, Alexander James, author.

Title: An introduction to U.S. collective bargaining and labor relations / Harry C. Katz, Thomas A. Kochan, and Alexander J.S. Colvin.

Other titles: Introduction to collective bargaining and industrial relations | Introduction to US collective bargaining and labor relations

Description: Fifth edition. | Ithaca : ILR Press, an imprint of Cornell University Press, 2017. | Includes bibliographical references and indexes. Identifiers: LCCN 2017015903 (print) | LCCN 2017020593 (ebook) | ISBN 9781501713897 (epub/mobi) | ISBN 9781501713880 (pdf) | ISBN 9781501713866 (cloth : alk. paper) | ISBN 9781501713873 (pbk : alk. paper)

Subjects: LCSH: Collective bargaining. | Industrial relations. | Collective bargaining-United States. | Industrial relations-United States.

Classification: LCC HD6971.5 (ebook) | LCC HD6971.5 .K38 2017 (print) | DDC 331.890973-dc23

LC record available at https://lccn.loc.gov/2017015903

Cornell University Press strives to use environmentally responsible suppliers and materials to the fullest extent possible in the publishing of its books. Such materials include vegetable-based, low-VOC inks and acid-free papers that are recycled, totally chlorine-free, or partly composed of nonwood fibers. For further information, visit our website at cornellpress.cornell.edu. 